\title{
HAEMOPHILUS INFLUENZAE MENINGITIS-TREATED WITH PARENTERAL AND INTRATHECAL PENBRITIN
}

\author{
J. D. PickuP, M.D., D.C.H. \\ B. S. Mathur, M.B.B.S., D.C.H. \\ Senior House Officer in Padiatrics
}

Consultant Padiatrician, Pontrefract and Wakefield Group of Hospitals

\begin{abstract}
Ampicillin (Penbritin), a new synthetic penicillin was introduced in 1961 (Rolinson and Stevens, 1961 ; Brown and Acred, I96r; Knudsen, Rolinson and Stevens, 196I). We report two cases of hamophilus influenza meningitis which failed to respond to the usual antibiotics and were ultimately treated with intramuscular and intrathecal Penbritin.
\end{abstract}

\section{Case I}

A. K., aged $4 \frac{3}{4}$ months, was admitted on I 3.1 .63 with a three days' history of vomiting, pallor and fever.

On admission he had a temperature of $103^{\circ} \mathrm{F}$, there was marked neck rigidity, Kernig's sign was positive and the fontanelle was bulging and tense. The throat was congested and the head circumference was $17 \frac{1}{\text { in. }}$ There were no other neurological signs. Both plantar responses were flexor and the optic discs were normal.

Investigations. The CSF was turbid, not under pressure and contained macroscopic particles of pus. Proteins $200 \mathrm{mg}$., sugar $5 \mathrm{mg}$., chlorides $660 \mathrm{mg}$. $/ 100$ ml., globulins not increased. Cell count 3,500/cu. mm. 95\% polys., 5\% Monos. Gram staining revealed gram negative coccobacilli and on culture there was a light growth of hamophilus influenza sensitive to penicillin. Sensitivity against other antibiotics was not done. $\mathrm{Hb} .65 \%$ (Haldane), wbc $13,500 / \mathrm{cu}$. mm., polys. $35 \%$ : lymphs. $41 \%$, Monos. $5 \%$, eosinos. $1 \%$. A throat swab grew scanty colonies of staphylococcus albus, coagulase negative, sensitive to penicillin, chloramphenicol, streptomycin and tetracycline. Urine examination and chest radiograph were normal.

Initially, intrathecal penicillin and streptomycin were given and the patient was put on penicillin 250,000 units im. six hourly, sulphadimidine $0.25 \mathrm{~g}$. six hourly, streptomycin $0.25 \mathrm{~g}$. twice daily and cortisone acetate $20 \mathrm{mg}$. daily, orally. After receiving the CSF report intrathecal streptomycin $40 \mathrm{mg}$. and hydrocortisone $5 \mathrm{mg}$. intrathecally, daily, were started. As the patient did not show any response, on 16.1 .63 penicillin was replaced by chloramphenicol $75 \mathrm{mg}$. six-hourly orally. There was a clinical improvement but the temperature did not settle and the CSF flow was also noticed to be diminishing. On 18.1 .63 the temperature rose to $103{ }^{\circ} \mathrm{F}$ and he had generalized convulsions which were controlled with sedatives. By this time the CSF had become sterile and biochemically improved and the cell count diminished but slight xanthochromia was noticed at this stage. On 24.1.63 sulphadimidine and streptomycin were stopped and oral Penbritin 125 mg. six-hourly was added to the treatment. Unfortunately he started vo miting and Penbritin was stopped and chloramphenicol was changed to the intramuscular preparation.
CSF xanthochromia increased and became very thic with macroscopic pus particles. On 24.1.63 all other. treatment was stopped and he was given intramusculaf Penbritin $125 \mathrm{mg}$. six-hourly and from the next dax Penbritin intrathecally $5 \mathrm{mg}$. daily and intratheca hydrocortisone was added to the treatment. His con dition once again deteriorated suddenly, he refusefos feeds, became unconscious; there was slight ptosis of the left eye and bilateral intermittent nystagmus appeare $\$$ with left hemiplegia. Both the carotid arteries were palpable and the plantar responses were extensor and the optic discs were normal. Intrathecal Penbritin was given for ten days along with intramuscular Penbriti which was continued for three weeks. The temperature returned to normal after a week's treatment and \&eఠ mained normal. The CSF gradually improved andक्रि 5.2.63 was clear; proteins $50 \mathrm{mg}$., sugar $30 \mathrm{mg} / \mathrm{r} 00 \mathrm{mb}$ and no cells were seen. Clinical improvement contin and gradually movement on the left side returned. $A$ the time of discharge on 18.2.63 the CSF was normalo he was moving the left leg and arm slightly. One weef after discharge his general condition was excellent and he was kicking both legs equally. Two months after discharge there was little difference in the muscle ton and the reflexes on the two sides.

\section{Case 2}

C. S., aged 5 years, was admitted on 19.12 .62 with three days' history of being unwell, anorexia, headache $\frac{0}{3}$ drowsiness and vomiting. On examination he was very drowsy and listless with marked neck rigidity and positive Kernig's sign. The temperature was $100^{\circ} \mathrm{F}$. There were no other neurological signs. The CSF was very turbid and under increased pressure. Proteins $400 \mathrm{mg}$., sugar $15 \mathrm{mg}$./100 ml., cells $18,410 / \mathrm{cu}$. mm. Gram staining revealed gram-negative bacilli and on culture there was a moderate growth of hamophilus influenza Pitman type B. sensitive to penicillin, chloram을 phenicol, streptomycin, erythromycin and tetracycline After an initial dose of intrathecal penicillin and streptomycin treatment continued with chloramphenicol $125 \mathrm{mg}$. six-hourly im., streptomycin $40 \mathrm{mg}$., b.d. sulphadimidine I g. six-hourly. After receiving the CSF report, intrathecal streptomycin $40 \mathrm{mg}$. was given daily for three days. Twelve days later the temperature was normal but he remained fretful, irritable an complained of occasional headaches. The CSF ond 29. 12.62 showed $\mathrm{I} 89 \mathrm{cells} / \mathrm{cu}$. $\mathrm{mm}$. and was sterile or? culture. A repeat CSF on 3.1 .63 showed 140 cells/cu. $\mathrm{mm}$., proteins $50 \mathrm{mg}$., sugar $46 \mathrm{mg}$./100 $\mathrm{ml}$. and culture revealed a moderate growth of hamophilus influenze sensitive to penicillin, streptomycin, chloramphenicoh and erythromycin. In view of the relapse, sulphadimi 


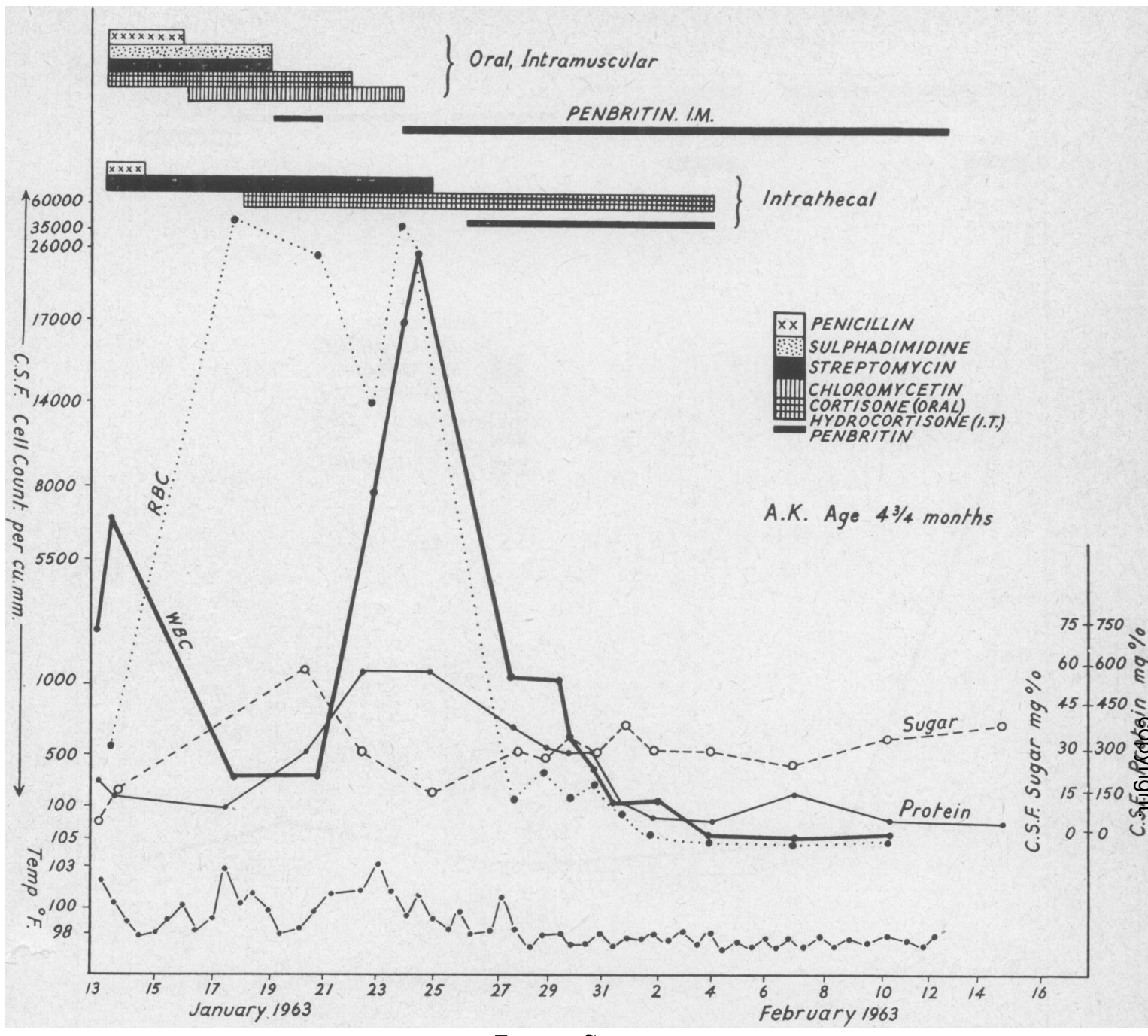

Fig. I.-Case I.

dine, chloramphenicol and streptomycin were recommenced on 3.1 .63 for a week with daily intrathecal streptomycin for three days. The temperature remained normal and the general condition markedly improved. The CSF on I 1.1.63 was clear; proteins $30 \mathrm{mg}$./ $100 \mathrm{ml}$., cells $66 / \mathrm{cu}$. mm. Culture revealed a moderate growth of hamophilus influenze sensitive to chloramphenicol, streptomycin, sulphadimidine and penicillin. In view of the second relapse and failure to respond to the usual treatment, it was decided to try Penbritin which was given in doses of $250 \mathrm{mg}$. six-hourly orally which was continued until 17.1.63. On that day the CSF was still turbid and showed 73 cells $/ \mathrm{cu}$. mm., proteins $40 \mathrm{mg}$., sugar $86 \mathrm{mg} . / 100 \mathrm{ml}$. and was sterile on culture. Another course of Penbritin was started on 19.1.63. The CSF on 25.1.63 was once again turbid with 213 cells/cu. mm., proteins $70 \mathrm{mg}$., sugar $63 \mathrm{mg} . / 100 \mathrm{ml}$. and on culture gram-negative bacilli were grown which were later proved to be paracolon bacilli, probably contaminants. A third course of oral Penbritin was started on 26.1 .63 and on 29.1.63 it was changed to intramuscular Penbritin $125 \mathrm{mg}$. six-hourly which was given for five days. A single dose of intrathecal Penbritin $10 \mathrm{mg}$. was also given. The CSF at the end of the treatment was normal and sterile on culture. He was discharged on 6.2.63 and the CSF was normal. He has been well since his discharge home.

\section{Discussion}

Penbritin, a new broad spectrum antibiotic, is well known for its effectiveness against gram negative organisms. Activity of Penbritin in vivo against infections produced by gram negative organisms is considered to be greater than that of tetracycline and chloramphenicol (Brown and Acred, 196r). Against hamophilus influenzoe Penbritin showed a high level of activity; twice as high as penicillin G., and chloramphenicol and five times greater than tetracycline (Rolinson and Stevens, 196r). Peak serum concentration of the drug is obtained in about one to two hours and a significant serum concentration $(0.2 \mu \mathrm{g} / \mathrm{ml}$.) is still 


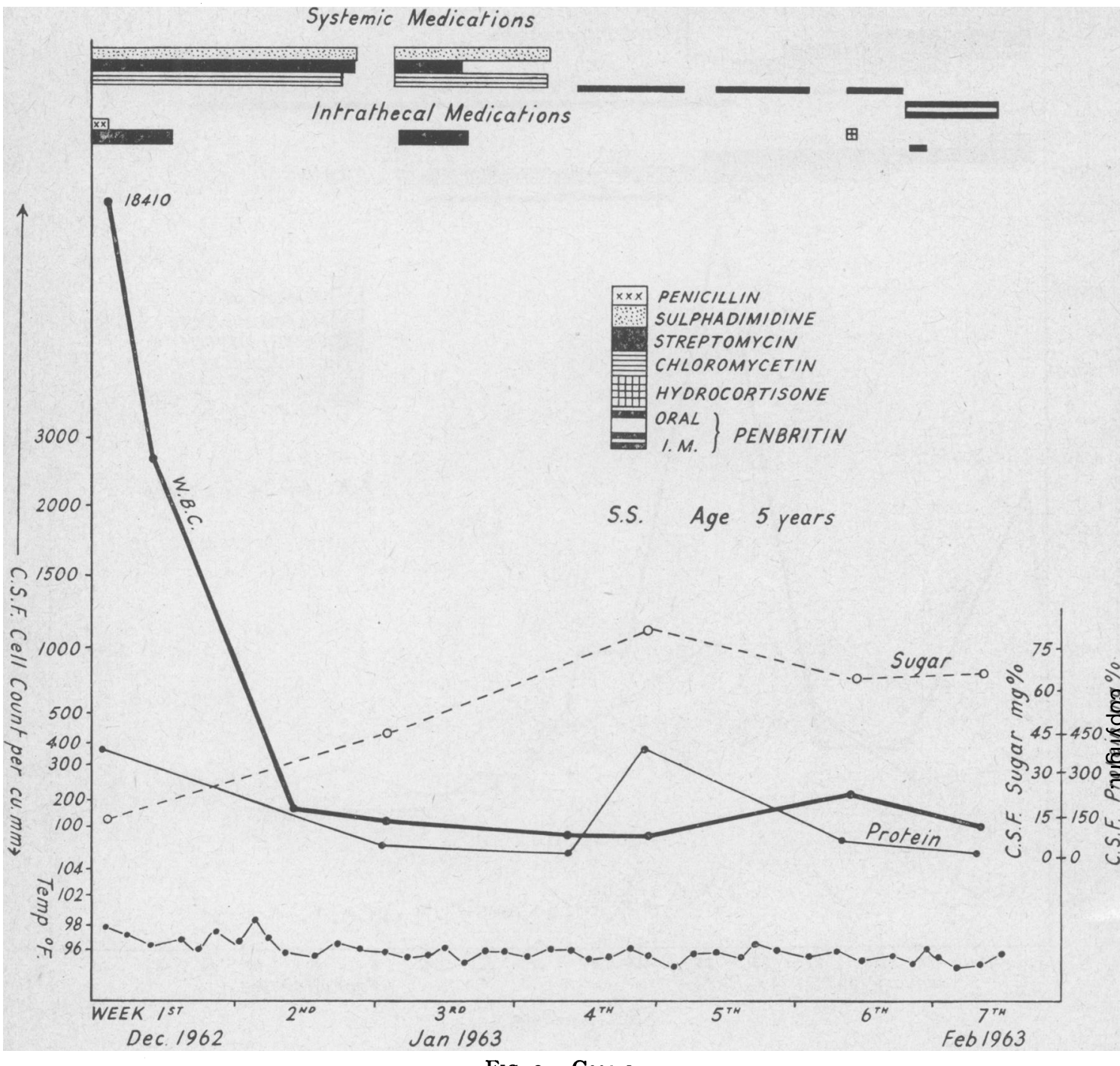

Fig. 2.-Case 2.

present after six hours if the drug is given in doses of $100 \mathrm{mg} . / \mathrm{kg}$. per day orally, minimum inhibitory concentration for hamophilus influenze being 0.1 to $0.5 \mu \mathrm{g} / \mathrm{ml}$.

Only three cases have so far been reported where Pebritin has been used in meningitis. Two of them were adult cases with $E$. Coli meningitis following a serious head injury and CSF leak (Spittle and Philips, I96r). After oral administration of Penbritin the CSF level in two to three hours was less than $0.2 \mu \mathrm{g} / \mathrm{ml}$. and after six hours it rose to $2.42 \mu \mathrm{g} /$ ml. A CSF level of $12.5 \mu \mathrm{g} / \mathrm{ml}$. has been observed after ro mg. of intrathecal Penbritin after six hours; doubling the dose virtually doubles the peak serum concentration which is not seen with tetracycline (Knudsen and others, 196r). Similarly, doubling the intrathecal dose up to $40 \mathrm{mg}$. increases its 옥 concentration in the CSF without any sign of $D$ cerebral irritation (Spittle and Phillips, 196r).

Another case, that of a hydrocephalic child aged $\mathrm{N}$ 9 months with urinary infection due to coliform 9 bacilli and streptococci has been described, who $N$ developed meningitis in which the CSF yielded N strains of streptococci (Stewart, Coles, Nixon and Holt, 196r). This child was treated with oral

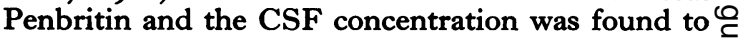

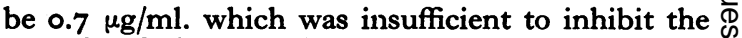
growth of the organisms. Intraventricular Pen-? britin, 2 to $4 \mathrm{mg}$. daily for four days, produced a $T$ CSF concentration of more than $20 \mu \mathrm{g} / \mathrm{ml}$. which

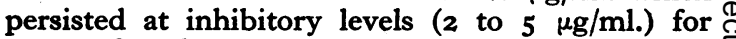
twenty-four hours or more. 


\section{Summary}

Two cases of hamophilus influenza meningitis have been described who showed lack of response to the routine antibiotics. These two cases did not respond to the oral Penbritin because of vomiting and were treated with intramuscular and intrathecal Penbritin with successful results as shown by biochemical and clinical responses. It should be stressed that neither of these preparations of
Penbritin is yet available on the market; both were obtained by special arrangements. We consider that these routes of administration of Penbritin would be useful in the treatment of patients with hamophilus influenza meningitis.

We would like to thank the Beecham Research Laboratories Ltd., for the generous supplies of both intramuscular and intrathecal Penbritin at very short notice.

\title{
REFERENCES
}

Brown, D. M., and ACred, P. (196I): 'Penbritin'-a new broad spectrum antibiotic. Preliminary Pharmacology and Chemotherapy, Brit. med. F., ii, 197.

KNudSEn, E. G., Rolinson, G. N., and Stevens, S. (196I): Absorption and Excretion of 'Penbritin', Ibid, ii, 198. Rolinson, G. N., and Stevens, S. (1961): Microbiological Studies on a New Broad-Spectrum Penicillin 'Penbritin', Ibid, ii, 191.

Spittle, C. R., and Phillips, B. M. (1962): A case of E. Coli Meningitis treated with Systemic Intrathecal Ampicillin, Postgrad., med. F., 38, 168.

Stewart, G. T., Coles, H. M. T., Nixon, H. H., and Holt, R. J. (196r): 'Penbritin': An oral Penicillin with BroadSpectrum Activity, Brit. med. F., ii, 200.

\section{FIBRINOLYSIN THERAPY IN ARTERIAL THROMBO-EMBOLISM}

\author{
R. Nambiar, M.B., F.R.C.S.Ed., Surgical Registrar \\ M. Lentin, M.B., F.R.C.S.Ed., Consultant Surgeon \\ From the Vascular Clinic, Royal Infirmary, Bolton
}

THE lysis of intravascular clot using thrombolytic substances has been achieved by various workers since Cliffton, Grossi and Cannamela (1954) originally demonstrated the effect of fibrinolysin in venous thrombosis in 1954. A vast amount of literature has accumulated on the therapeutic uses of such drugs especially in the United States of America. In this country, thrombolytic therapy using streptokinase has recently been reported (Verastraete, Amery, and Verylan, 1963; and McNicol, Reid, Bail and Douglas, 1963). Our experience with fibrinolysin (Actase) therapy has been limited but favourable. The following cases are particularly significant:-

\section{Case No. I}

A woman (A. H.) aged 64 years was admitted on 8.2.63 with colicky abdominal pain of twenty-four-hours' duration and constipation for two days. Her abdomen was moderately distended in the lower part and a straight X-ray showed some distention of the small intestine (Fig. I).

A diagnosis of subacute intestinal obstruction was made and was treated on conservative lines with a satisfactory response.

She had had a sub-total thyroidectomy ten years ago. She had a blood pressure of $180 / 100 \mathrm{~mm}$. Hg. and auricular fibrillation was noted. The chest $X$-ray and ECG were compatible with the diagnosis of mitral valve disease. She had no previous history of intermittent claudication.

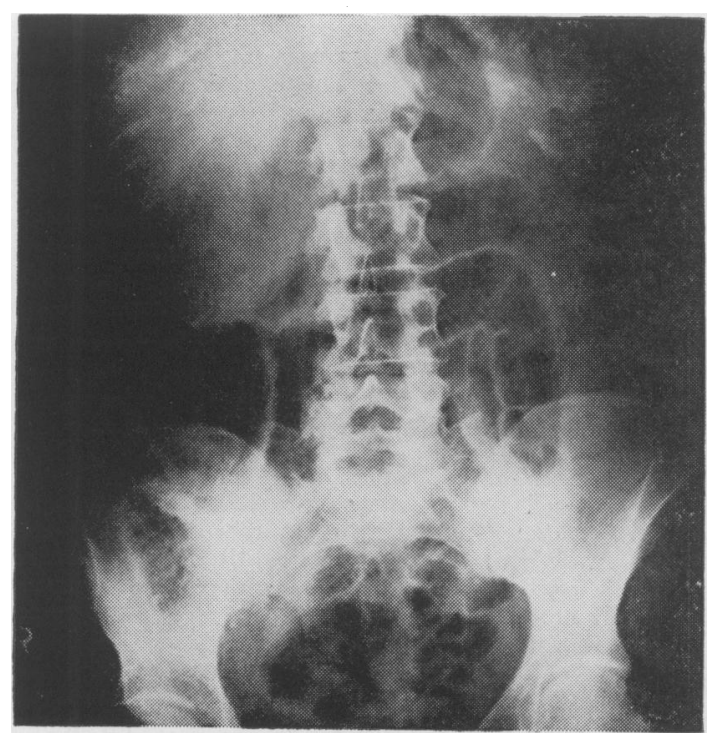

Fig. 1.-Case I.

On 12.2.63 she suddenly developed loss of sensation of her left foot and toes. On examination, the left foot and toes were extremely pale and cold. There was no 